\title{
Impact of IFRS on the quality of financial information in the United Kingdom and France: Evidence from a new perspective
}

\author{
Héctor Fabio Perafán Peña(iD, Julián Benavides Franco(iD \\ Universidad ICESI (Colombia) \\ hpperafan@icesi.edu.co, jbenavid@icesi.edu
}

Received November, 2016

Accepted July, 2017

\section{Abstract}

Purpose: To assess the impact of the mandatory adoption of the International Financial Reporting Standards (IFRS) on the quality of the financial information available on listed companies in the UK and France.

Design/methodology: This research uses panel regressions to analyze the relationship between the idiosyncratic risk of stock returns and the opacity of financial reports, before and after the mandatory adoption of IFRS. Opacity calculations include different proxies of earnings management, according to the models used in the literature for the estimation of discretionary accruals, as a robustness test.

Findings: Firm size influences the impact of IFRS in the UK, and the financial information of larger firms seems to have improved after IFRS adoption. In the case of France, the results do not support any improvement in the quality of the financial information after IFRS were put in place.

Research limitations/implications: This research applies a new methodological approach to study the impact of IFRS adoption, but additional inquires on the subject are surely required. 
Practical implications: Certain features of the countries, such as the Common Law legal system and enforcement, could explain why the quality of the financial information for large firms has increased following the adoption of IFRS. It seems that the implementation of IFRS has given investors additional elements with which to ascertain a firm's ability to generate future cash flows.

Social implications: The adoption of IFRS, by itself, is not enough to improve the quality of financial information. Thus, regulators in countries adopting IFRS should consider additional reforms to ensure that the desired results are achieved.

Originality/value: This work overcomes the methodological design problems of previous research, such as sample selection bias, the inclusion of observations close to the year of mandatory adoption, the heterogeneity of each country and the size of the analyzed companies. To the best of our knowledge, this research is the first to test the effect of IFRS adoption in the European context, using the relation between idiosyncratic risk and the opacity of financial reports.

Keywords: Financial information quality, Earnings management, IFRS adoption

Jel Codes: M4, M48

\section{Introduction}

In 2002 the European Union (EU) approved the IAS Regulation, that requires listed companies to adopt, on a mandatory basis, the International Financial Reporting Standards (IFRS) for the preparation of their consolidated financial statements for the fiscal years starting as of January 1, 2005 (Aisbitt, 2006; Brüggemann, Hitz \& Sellhorn, 2013; Daske, Hail, Leuz \& Verdi, 2008; Soderstrom \& Sun, 2007). Its purpose is to ensure a high level of transparency and comparability of financial information, thus attempting to obtain an efficient operation of the capital markets in the EU (Brüggemann et al., 2013). Some authors believe that the route selected by the EU, adopting a common language for financial reporting, is one of the most important regulatory changes made in this field during the last thirty years, if not throughout all of history (Jeanjean \& Stolowy, 2008; Daske et al., 2008; Doukakis, 2014). 
About this process, Brüggemann et al. (2013) indicate that research on the potential impact of the adoption of the IFRS in the EU is still in its early stages and requires closer scrutiny in order to assess its costs and benefits. Likewise, these authors stress that there are two types of consequences for the EU economy derived from this regulation: the expected and unexpected effects. With reference to the expected effects, other studies have focused on the impact that the IFRS have had (not only in Europe, but also in other parts of the world) on the quality of financial information, using "earnings management" (EM) as a proxy in this regard (Barth, Landsman \& Lang, 2008; Callao \& Jarne, 2010; Cang, Chu \& Lin, 2014; Doukakis, 2014; Jeanjean \& Stolowy, 2008; Pelucio-Grecco, Geron, Grecco \& Lima, 2014; Soderstrom \& Sun, 2007; Van Tendeloo \& Vanstraelen, 2005; Zéghal, Chtourou \& Sellami, 2011). The concept of EM, or earnings management, assumes that there is a certain amount of discretion on the part of management when it comes to preparing financial information, which enables them to alter the perception that external users of the financial reports, investors or creditors, have about a company's results (Healy \& Wahlen, 1999). A priori, for this research it is not clear whether the IFRS can boost or hamper EM, given that the effects generated against earnings management by highquality financial reporting standards, such as the IFRS, can be undermined by the use of fair value and greater flexibility that are permitted by these standards (based on principles) (Aisbitt, 2006; Callao \& Jarne, 2010; Cang et al., 2014; Doukakis, 2014; Soderstrom \& Sun, 2007). In this regard, different empirical studies on the topic offer different conclusions, and therefore there is no unanimity as to whether the IFRS have a positive or negative impact on EM, and consequently on the quality and transparency of financial information. In this regard, as Brüggemann et al. (2013) explain, the contradictory results in this literature can be conditioned by factors that emanate from the research methodology design.

This work adds to the discussion of the impact of the IFRS on the quality of financial information from a different perspective. The relationship between EM and shareholder returns has already been studied in the American context (Baber, Chen \& Kang, 2006; Beyer, 2009; Das, Kim \& Patro, 2011; Hutton et al., 2009; Kang, Liu \& Qi, 2010; Konan, Chan, Jegadeesh \& Lakonishok, 2006; Li, Francis \& Hasan, 2011). However, this has not been the case for European countries, in particular for the study of the impact the mandatory adoption of these standards has on the quality of the companies' financial information (measured as EM). This study thus uses the methodology implemented by Hutton et al. (2009) to study the effect the adoption of IFRS has on the relationship between EM and shareholder returns. Making use of the measures of opacity and idiosyncratic risk proposed by Hutton et al. (2009), here we study the effect of the mandatory adoption of the IFRS on the idiosyncratic risk of companies in the United Kingdom and France. The choice of these countries is justified by the fact 
that they did not allow the voluntary adoption of the IFRS prior to 2005, since as established by other research (Barth et al., 2008; Doukakis, 2014; Jeanjean \& Stolowy, 2008), studies on the adoption of IFRS can include a selection bias by studying countries that permitted the voluntary adoption of these standards. Furthermore, the United Kingdom and France exhibit large differences in terms of their legal systems and the rigor with which they apply accounting standards, factors which have been identified as far-reaching when it comes to evaluating the effect the adoption of IFRS can have on the quality of the financial information (Brüggemann et al., 2013; Daske et al., 2008; Doukakis, 2014; Jeanjean \& Stolowy, 2008; Liao, Sellhorn \& Skaife, 2012; Soderstrom \& Sun, 2007; Von Koch, Nilsson, Jonsson \& Jansson, 2014).

The results of this work indicate that it is only when the size of the companies is taken into account that it becomes possible to appreciate the fact that the IFRS have a positive impact on the quality of financial information, by reducing the negative correlation between opacity and the idiosyncratic risk of the shareholder returns of the largest companies. Of course, this is consistent with the heterogeneity characteristic of each country and thus it is only possible to observe that behavior for the United Kingdom, which unlike France, has a Common Law legal system and demands great rigor in terms of compliance with accounting rules. Finally, there is a series of events that we believe deserve closer scrutiny, which could be addressed in future studies. In this sense, it is interesting to note that judging from the tests conducted, it could be inferred that IFRS reduce the idiosyncratic risk of the shareholder returns for companies in these countries. In contrast to this and the conclusions reached in this study, it must be stressed that this is a pioneering approach to the evaluation of the effects of the mandatory adoption of IFRS, from the perspective of the analysis of the relationship between EM and the companies' idiosyncratic risk, and does not intend to reach any conclusive results on this topic; rather, it seeks to provide support for other methods that might help measure the effects of the IFRS on the quality of financial information in the $\mathrm{EU}$ in the future, taking into account the improvement opportunities for the empirical approaches implemented so far.

The following section reviews the literature and proposes the hypotheses that guide this work. Next, the research design is discussed in the 3 section. The 4 and 5 sections present the results of the regression analyses, while the 6 and 7 sections discuss and draw conclusions about the results of this study. Finally, sections 8 and 9 contain the appendixes and the bibliography, respectively. 


\section{Review of the literature and proposal of the hypotheses}

Research on the adoption of IFRS and the effect they can have on the quality of financial information varies, insofar as:

- it is not limited to the European context, rather it discusses their impact on emerging economies, such as China and Brazil; and

- there are differing views on the effect these standards have on the quality of financial reporting.

Likewise, it is worthwhile to stress that one of the most common measures used to assess the quality of financial information is EM, which is negatively associated with the quality of financial information (Barth et al., 2008; Soderstrom \& Sun, 2007; Von Koch et al., 2014).

Accordingly, Barth et al. (2008) conducted a study on 21 developed and emerging countries (which included Switzerland, China and Germany, among others), their findings indicate that the implementation of IFRS is negatively associated with EM. Along these same lines, Zéghal et al. (2011) found that in the case of France, for those companies with good levels of corporate governance that depend on foreign financial markets, the adoption of IFRS is negatively related to EM. In the case of Brazil, Pelucio-Grecco et al. (2014) show that the implementation of full IFRS plays a restrictive role on EM in listed companies. On the contrary, Callao and Jarne (2010) and Cang et al. (2014) indicate that, for the EU and China, the adoption of these standards is positively associated with EM. Both studies agree in stating that IFRS make financial information more flexible and subjective, through the criteria for the valuation and recognition of the elements of the financial statements, among which the use of reasonable value stands out. On the other hand, Jeanjean and Stolowy (2008) conducted a study on Australia, France and the United Kingdom in which they found that EM remains stable in Australia and the United Kingdom, and only increases in France once the IFRS are adopted. Similarly, Doukakis (2014) found that for 22 European countries between 2000 and 2010, the mandatory adoption of IFRS had no significant impact on earnings management based on accruals and real activities. In addition, Van Tendeloo and Vanstraelen (2005) determined that in Germany, the perceived EM for companies that adopted IFRS showed no different behavior as compared to those that reported their financial statements according to German accounting principles.

It is evident that empirical studies considering the impact of IFRS on the quality of financial information fail to draw any single conclusion. This may be due to aspects related to the design of the research methodology that is used by the authors. Brüggemann et al. (2013) confirmed this by 
indicating that certain problems in the design of the studies are responsible for the mismatch between the empirical evidence against the increase in the comparability and the transparency of information, product of the mandatory adoption of the IFRS in the EU, and the benefits at a macroeconomic level and in the capital markets validated in this group of countries after 2005.In this context, authors such as Barth et al. (2008), Doukakis (2014) and Jeanjean and Stolowy (2008) argue that there is a selection bias problem for those studies that compare the quality of the companies' financial information before and after the adoption of the IFRS, because they do not distinguish between the countries that allowed the voluntary adoption of these standards before 2005 and those that did not. This problem lies in the fact that the companies that receive benefits or product advantages from the implementation of IFRS will have an incentive to do so before the established deadline, which can exacerbate the effects of these standards on the quality of the financial statements (Jeanjean \& Stolowy, 2008). Moreover, uncertain effects on EM have also been identified in the years soon after the transition from local rules to IFRS (Jeanjean \& Stolowy, 2008), which is in line with other studies that have been conducted on the adoption of IFRS that indicate the noticeable effect the figures of the income statement and the balance sheet can have (Aisbitt, 2006; Capkun \& Cazavan-Jeny, 2008; Cormier, Demaria, LapointeAntunes \& Teller, 2009; Haller, Ernstberger \& Froschhammer, 2009).

Taking this into account, this research contributes to the discussion on the impact that IFRS have on the quality of financial information in the EU, from a perspective that has not been considered so far, as indicated by the review of the literature. In this regard, while it can be established that studies on the mandatory adoption of IFRS in the EU have concentrated on two lines, the first on the analysis of the stock market reactions, and the second on the discussion of the effects on the financial statements (Daske et al., 2008), it has not been assessed whether the mandatory adoption of these standards has any effect on the relationship between the quality of the financial information (measured as EM) and shareholder returns; it is in this aspect that this research contributes to the literature concerning the discussion of the mandatory adoption of IFRS in the EU.

With regard to the relationship between EM and shareholder returns, works such as that by Kang et al. (2010) indicate that the discretionary accruals have a predictive power on the market returns that is larger than that of normal accruals, which implies that when only the relationship between total accruals and shareholder returns is analyzed, this negates the discretion a company's management has when it comes to manipulating its financial information and impacting the price of its shares on the stock market. Das et al. (2011), in turn, found that the administrators of companies traded on the capital market use EM and expectation management as supplements or replacements, with the aim of 
generating net returns on the share prices of the companies they manage. The work by Baber et al. (2006) concluded that the early disclosure of information on the financial status of a company can help the market assess whether the earnings announcements by a particular company are being altered by EM. On the other hand, Konan et al. (2006) concluded that the accruals are negatively related to future returns and that non-discretionary or normal accruals do not reveal any predictive power in terms of these returns. Likewise, they conducted a study parallel to this one, which considered ordinary shares from non-financial companies in the USA, on the United Kingdom, stressing that this was the first time that an analysis of this type had been carried out in for the latter country.

In addition to the above-mentioned studies, we should also mention that by Hutton et al. (2009). These researchers proposed a measurement of the opacity of the financial information that makes use of EM and established that it has a negative relationship with the idiosyncratic risk of the shares. This is due to the fact that if there is less specific information about the firm, product of the EM, and the share price returns for that company will be explained to a greater extent by the systematic risk than by the idiosyncratic risk.

\subsection{Hypothesis 1}

Based on the analysis by Hutton et al. (2009) and the empirical evidence found in the literature on IFRS adoption, the first hypothesis of this study is proposed: Prior to the adoption of IFRS, there was a negative relationship between the opacity and the idiosyncratic risk measurement; this relationship will remain the same (or differ), depending on whether those factors inherent to the mandatory adoption of the IFRS and that support the EM dominate (or not) over those that restrict it. Thus, although it is to be expected that the IFRS favor an improvement in the quality of financial information, as they are high-quality standards (in relation to many generally accepted accounting principles used locally in the EU), it is also true that they significantly rely on the use of professional judgment and private information from companies, which along with valuation criteria such as fair value, provide greater flexibility to management when it comes to preparing financial statements (Barth et al., 2008; Callao \& Jarne, 2010; Cang et al., 2014; Daske et al., 2008; Doukakis, 2014; Jeanjean \& Stolowy, 2008). 


\subsection{Hypothesis 2}

In addition to the above, various authors have also concluded that the impact of the implementation of IFRS depends on external factors that may be specific to each country (Brüggemann et al., 2013; Daske et al., 2008; Doukakis, 2014; Jeanjean \& Stolowy, 2008; Liao et al., 2012; Soderstrom \& Sun, 2007; Von Koch et al., 2014). Among the most important elements that affect the IFRS are laws and regulations that have been passed prior to their implementation, the political and legal system, the rigor with which the accounting standards are applied, property structures, mechanisms of corporate governance, economic development, the importance of the capital markets and similarity between the generally accepted accounting principles and the IFRS. Accordingly, the second hypothesis of this study indicates that it is expected that the relationship between the opacity and the idiosyncratic risk measurement after the mandatory adoption of the IFRS is conditioned by the heterogeneity characteristic of each country.

\subsection{Hypothesis 3}

Several works in the literature on EM and the adoption of the IFRS have indicated the role that might be played by the size of the companies. In this sense, earnings manipulation would in many cases be tied to the size of the company, as the larger and more profitable a company is, the greater the incentives are by the authorities to scrutinize its financial statements, which is why this type of companies tend to reduce their level of EM (Beekes, Pope \& Young, 2004; Van Tendeloo \& Vanstraelen, 2005; Watts \& Zimmerman, 1990). Likewise, the literature on IFRS adoption has also shown the differentiating role played by company size in the accounting policies they adopt, their effects on assets and net profits, and the costs and benefits received upon implementing these standards (Eierle \& Haller, 2009; Goodwin \& Ahmed, 2006; Nobes \& Perramon, 2013). Therefore, it is to be expected that the relationship between the opacity and idiosyncratic risk of the shareholder returns would not be the same for companies of different sizes after the mandatory adoption of IFRS in 2005. 


\section{Research methodology}

\subsection{Sample}

Taking into account the hypotheses proposed and the previous review of the literature, this research studies the effects on opacity and idiosyncratic risk for companies traded on the stock markets in the United Kingdom and France. These two countries were selected based on the fact that they both have highly developed stock markets (Konan et al., 2006; Liao et al., 2012), different legal systems (a Common Law system in the case of the United Kingdom and a Civil Code in France), and differences in the rigor with which the accounting standards are applied (Clarkson, Hanna, Richardson \& Thompson, 2011; La Porta, Lopez-de-Silanes, Shleifer \& Vishny, 1998). In a similar manner, in order to address the problem of selection bias, it was not possible to voluntarily adopt the IFRS before 2005 in either France or the United Kingdom (Jeanjean \& Stolowy, 2008).

Once the countries to be analyzed were selected, the data available in Bloomberg were downloaded to determine the closing prices, shares in circulation and information on the financial statements of the ordinary shares in the United Kingdom and France. For each country and based on the analysis by Hutton et al. (2009), a series of filters was applied to the sample, related to the measurements of idiosyncratic risk and opacity. Accordingly, first of all, in accordance with standard practice in the literature, those companies related to financial services and utilities were eliminated from the sample. Later, in order to calculate the idiosyncratic risk of the companies' shares, those observations (company-year) that do not have enough information to calculate at least 26 weeks of shareholder returns per fiscal year were excluded from the sample. Likewise, for the case of EM and opacity, those firms that did not provide enough information in their financial statements to calculate the discretionary accruals (DA) were excluded. At this regard, DA correspond to the EM measurement used by this study and which will be discussed in greater depth later.

In this manner, the samples corresponding to both countries initially included observations (companyyear) covering a period from 1991 to 2014, and totaling 10,269 for the United Kingdom and 5,915 in the case of France. However, it is important to note that by using the analysis by Hutton et al. (2009) which relies on accounting and market information to corroborate the relationship between idiosyncratic risk and opacity before and after the adoption of IFRS in 2005 for the United Kingdom and France, it is necessary to further restrict the sample in order to deal with the effect of outliers. As a result, the observations are limited to those companies that have market book value ratios between 10 and 1 and return on equity (ROE) with an absolute value of less than $100 \%$. However, it is also 
essential to purge the sample of any effects that the years following the adoption of the IFRS in 2005 might have on the financial information, as indicated in the previous section. Hence, this study does not take into account information from the financial statements corresponding to 2006. Therefore, taking into account the fact that opacity requires at least three time lags in the discretionary accruals (measured from the EM) for its calculation, the sample is limited to 3,677 observations for the United Kingdom (1995-2005; 2007-2014) and 2,941 for France (1992-2005; 2007-2014). The descriptive statistics for the sample can be found in Appendix B.

\subsection{Econometric Model}

The idiosyncratic risk of a stock (Hutton et al., 2009) is estimated through the coefficient of determination from a regression analysis of the variation of the weekly returns on the share price as function of the market and industry returns (the sectors of the Global Industry Classification Standard were used to identify the industries in each country.). Eq. 1 indicates the regression that enables us to calculate the coefficient of determination or r-squared used to estimate the idiosyncratic risk:

$$
r_{c, t}=\beta_{c}+\beta_{1, c} r_{s, t}+\beta_{2, c} r_{s, t-1}+\beta_{3, r} r_{s, t+1}+\beta_{4, c} r_{m, t}+\beta_{5, c} r_{m, t-1}+\beta_{6, c} r_{m, t+1}+\varepsilon_{c, t}
$$

The market $\left(r_{m}\right)$ and industry $\left(r_{s}\right)$ returns are estimated by calculating the continuous weekly returns of a portfolio, weighted by the value for each case. According to this approach, the systematic risk of a company's stock returns is estimated by the r-squared of Eq. 1. Therefore, the r-squared of the regression, which explains the continuous returns of the stock $\left(r_{c}\right)$, is used to calculate the idiosyncratic risk of the stock, according to Eq. 2:

$$
\text { Idiosync. Risk }=\ln \left(\frac{1-R^{2}}{R^{2}}\right)
$$

On the other hand, the opacity measurement, which is used as a proxy of the quality of the financial information, uses the EM, which in turn is calculated based on the DA. Hutton et al. (2009) indicate that their proxy of opacity corresponds to a measure of the transparency of financial reporting, based on the fact that EM is a measure of transparency. In this study, it is assumed that the opacity variable corresponds to a proxy of the quality of the financial information, due to is derived from a measure of $\mathrm{EM}$, since as indicated in the previous section, EM is considered in the literature on IFRS adoption as a variable that has a negative correlation with the quality of the information contained in the financial statements. This work uses the Modified Jones Model (Dechow, Sloan \& Sweeney, 1995) to estimate the 
$\mathrm{DA}$, as its predictive power to detect DA is greater than that of other existing models, and it is more commonly used in research employing DA as a proxy of EM (Dechow, Hutton, Kim \& Sloan, 2012; Dechow et al., 1995; Doukakis, 2014). The Modified Jones Model indicates that it is necessary to estimate the errors of the following regression in order to calculate the DA:

$$
\frac{T A_{t}}{\text { Ass }_{t-1}}=\alpha_{0} \frac{1}{A s s_{t-1}}+\beta_{0} \frac{\Delta \text { Sales }_{t}-\Delta A R_{t}}{A s s_{t-1}}+\beta_{1} \frac{\Delta P P E_{t}}{A s s_{t-1}}+\varepsilon_{t}
$$

In this case, the regressions are estimated by industry groups in each year, ensuring that there are at least eight observations per sector in order to perform the regression (Doukakis, 2014). In this manner, in Eq. 3 the total accruals of a company $\left(T A_{t}\right)$ are regressed according to the variation in sales, discounting the effect of the variation on accounts receivable $\left(\Delta\right.$ Sales $\left._{t}-\Delta A R_{t}\right)$ and the variation of the property, plant and equipment account $\left(\triangle P P E_{t}\right)$, all of which is scaled by the first lag in total assets $\left(A s_{t-1}\right)$. The figures for the estimated errors of the previous regression are the measure of DA used as a proxy of the EM of a company. With this information, the opacity is calculated (Hutton et al., 2009) in the following manner:

$$
\text { Opacity }=A b s V \cdot\left(D A_{t-1}\right)+A b s V \cdot\left(D A_{t-2}\right)+A b s V \cdot\left(D A_{t-3}\right)
$$

The sum of the absolute values $(A b s V$.) of the discretionary accruals $(D A)$ constitutes a better proxy for the quality of the financial information than the EM measured by the DA, since if a firm has a highly positive level of DA in a certain period, it is to be expected that this will be reversed in the following period, showing as a result highly negative DAs, which is penalized in the Eq. 4 by taking into account the absolute value of the DAs, which may not be considered by observing only the individual DAs for each year.

The analysis of the relationship between the idiosyncratic risk of a company's stock returns $\left(I R_{i t}\right)$ and the opacity of its financial information (Opacity it $_{\text {) }}$ is performed by a regression in which the variation of the idiosyncratic risk of a company is explained according to the opacity of its financial information and a series of control variables, among them: size (Size $e_{i t}$, measured as the natural logarithm of its market capitalization, the ratio of its market value (or market capitalization) and its book value (Market_book_val_ratio $i t)$, level of indebtedness (Indebtedness $\left.s_{i t}\right)$, level of return on equity $\left(\mathrm{ROE}_{i t}\right)$, variation (Sector_variation ${ }_{i t}$ ), level of asymmetry (asymmetry coefficient) (Assymetry ${ }_{i t}$ ) and kurtosis (kurtosis coefficient) (Kurtosis $s_{i t}$ ) of the distribution of the stock returns from the portfolio of the industry to which the company belongs. 
In this way, the regression model that permits analyzing the effect of the adoption on the quality of financial information is the following:

$$
\begin{aligned}
I R_{i t}= & \beta_{0}+\beta_{1} \text { Opacity }_{i t}+\beta_{2} \text { Sector_variation }_{i t}+\beta_{3} \text { Size }_{i t}+\beta_{4} \text { Market_book_val_ratio }_{i t}+\beta_{5} \text { Indebtedness } \\
& + \\
& \beta_{6} \mathrm{ROE}_{i t}+\beta_{7} \text { Assymetry }{ }_{i t}+\beta_{8} \text { Kurtosis }_{i t}+\beta_{9} I F R S_{i t}+\beta_{10} \text { Opacity\#IFRS } S_{i t}+\varepsilon_{i t}
\end{aligned}
$$

The definition of these and other variables used in this study can be consulted in Appendix A. As indicated in the previous section, a priori, it is expected that the relationship between opacity and the idiosyncratic risk of a company would be negative.

\section{Results}

The results of the regressions of the idiosyncratic risk are consolidated below according to opacity and the control variables discussed in the previous section. Note that the potential effect of company size was taken into account in the correlation between the variables of interest (opacity and idiosyncratic risk), in such a way that a regression analysis is performed for large and small companies. Large companies were considered to be those above the 75th percentile for the size variable, while small companies were those below the 25th percentile. Likewise, in order to evaluate the effect of the adoption of IFRS on the relationship between opacity and idiosyncratic risk, we create a dummy

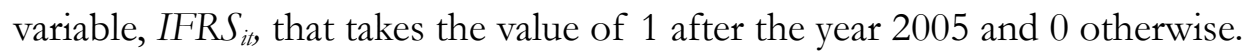

Panel A of Table 1 presents the results for the United Kingdom. Specifications 1 and 2 include all the firms; while specification 1 does not consider the adoption of the IFRS, 2 includes the dummy variable associated with the adoption and its interaction with opacity. In no case are the coefficients associated with opacity significant, although the positive sign of the interaction indicates a positive effect on the quality of the financial information during the period following their adoption. The structure of specifications 1 and 2 is replicated for the samples segmented by size (except for the size variable). Specifications 3 and 4 consider small companies for which, contrary to expectations and in contrast with the previous results, the association between opacity and the idiosyncratic risk of its stock returns is positive and significant. This effect is reduced to an important degree during the post-IFRS period: while the coefficient is 0.86 for the pre-IFRS period, this drops to just $0.021(0.86-0.839)$ in the postIFRS era, and moreover, this value is similar in magnitude to the overall result (0.022). Altogether, these results can be considered positively with regard to the effect of the adoption of IFRS on idiosyncratic risk, given that the spurious positive relationship, characteristic of the pre-IFRS period (this coefficient 
is probably affected by the dummy IFRS adoption variable, which is negative and significant. This also applies to specifications 4 and 6 ), is affected in the expected manner by the adoption of the rules. In spite of this, we must note that the r-squared value $(\approx 0.04)$ of the estimates corresponding to the smaller companies is low, and therefore we must be careful when interpreting the marginal effect of the opacity on the idiosyncratic risk before and after the IFRS.

For the large companies, specification 5, which eliminates the effect of the adoption of the IFRS on the correlation between opacity and the idiosyncratic risk of large companies in the United Kingdom, produces the opposite results of those for specification 3, reporting a negative correlation (nonsignificant) between opacity and the idiosyncratic risk for these companies, which corresponds to the expected result in the approach to Hypothesis 1. The results in specification 6 are also aligned with Hypothesis 1, given that the association between the idiosyncratic risk is negative in the pre-IFRS era, as well as with Hypothesis 2, as the relationship is noticeably diminished once the IFRS are implemented in the United Kingdom, increasing from -2.096 to $0.175(-2.096+2.271)$. It is important to point out that the variation in the idiosyncratic risk of large companies in the United Kingdom is explained to a large extent by the proposed model, and likewise, the adjusted r-squared of specification 6 is larger $(\approx 0.15)$ than that of specification $5(\approx 0.10)$, indicating that the structural change brought about by the implementation of the IFRS helps explain to a greater extent the variation in the idiosyncratic risk of large companies in the United Kingdom.

Panel B, corresponding to the analysis of French companies, is consistent with Hypothesis 1, as it reports a negative impact of the opacity of its financial information and the idiosyncratic risk of its shares for all specifications. In this regard, it is observed that the negative relationship is maintained and even magnified in specifications 1 and 2, which can lead to think that the adoption of IFRS exacerbates that association. When the effect of company size on this relationship is analyzed, we can confirm that in the case of smaller companies (specifications 3 and 4), the relationship between opacity and idiosyncratic risk is negative, and even through the post-IFRS effect is negative, it does not reach significant levels. Likewise, as in the case of the United Kingdom, the model used shows a poor fit for small companies. On the other hand, in spite of the fact that the r-squared of the regressions is higher for the largest companies (specifications 5 and 6) than for the previously analyzed group of companies, it could not be validated that the adoption of IFRS has any effect on the relationship between opacity and the idiosyncratic risk of the stock return, given that none of the variables associated with opacity are significant. However, unlike what is reported for the sample of companies in the United Kingdom, both opacity and its post-IFRS effect maintain the same signs in the different specifications, which 
suggests a negative effect on the quality of the financial information resulting from the adoption of IFRS.

In addition, it can be seen that, for both countries, the IFRS variable reflecting the effect of the adoption of IFRS on the variation in idiosyncratic risk not explained by the approach offered by Hutton et al. (2009) is significant and negative for all companies in general, and for large firms.

With regard to the control variables, it is interesting to note the significant negative impact of the size variable on the idiosyncratic risk, which is consistent with the findings of Hutton et al. (2009) and Roll (1988), suggesting that with larger sizes, it is more difficult to incorporate the informational effect specific to each firm from that offered by the sector and market.

\section{Robustness tests and notes on $\mathrm{R} 2$}

In addition to the analysis by Hutton et al. (2009) and in order to validate the findings of the previous section, a series of robustness tests were carried out. These re-estimated the opacity through the use of different models to calculate the DAs.

On an international level, different methodologies have been used to measure EM by means of DA. Pelucio-Grecco et al. (2014) reviewed the publications in this context for a period between the years 2008 and 2012, confirming the widespread use of the Jones Model (Jones, 1991), the Modified Jones Model (Dechow et al., 1995), the Modified Jones Model described by Kothari, Leone and Wasley (2005) and the Modified Jones Model described by Teoh, Welch and Wong (1998), with the models proposed by Dechow et al. (1995) and Kothari et al. (2005) being the most commonly used, with 24 and 18 publications, respectively (see Table 1, page 48 of the document by these authors). Likewise, PelucioGrecco et al. (2014) also indicate the virtues of the Kang and Sivaramakrishnan Model (1995) and its use in EM studies in Brazil. We also found support for the use of these models in the literature in works such as that by Louis (2004), Bergstresser and Philippon (2006), Cornett, Marcus and Tehranian (2008), Zéghal et al. (2011), Zhang, Uchida and Bu (2013), Cang et al. (2014) and Doukakis (2014).

Of the models mentioned for the calculation of DAs, it should be clarified that they are transformations of the Jones Model, including the Modified Jones Model used in the previous section. Accordingly, we will proceed to explain how each model estimates the DAs, based on the details provided in section 3.In this regard, the Jones Model, as compared to the Modified Jones Model, 
estimates the DAs by assuming that sales revenue is not susceptible to manipulation by management, hence it does not take into account the adjustment due to variation in accounts receivable $\left(\Delta A R_{t}\right)$ of Eq. 3 (Dechow et al., 1995). Teoh et al. (1998), in turn, use the Modified Jones Model without considering the variation in fixed assets $\left(\triangle P P E_{t}\right)$ of Eq. 3, as they argue that long-term accruals are less likely to be manipulated by management. With regard to the model proposed by Dechow et al. (1995), Kothari et al. (2005) indicate that it is necessary to contemporaneously include as a control variable, i.e., without any bias what so ever, return on assets (ROA), as the Modified Jones Model assumes that there is an increase in DAs when the firm is in a growth stage. At this point, we must highlight that the variables specified in Eq. 3 were scaled by the first lag of the total assets.

Furthermore, based on the KS Model, Kang and Sivaramakrishnan (1995) propose a method for calculating DAs using the estimated error of the following specification:

$$
\begin{aligned}
& \frac{T A_{t}}{A s s_{t-1}}=\alpha_{0}+\alpha_{1}\left(\frac{A R_{t-1}}{\text { Sales }_{t-1}}\right)\left(\frac{\text { Sales }_{t}}{A s s_{t-1}}\right)+\alpha_{2}\left(\frac{I n v_{t-1}+E P A_{t-1}-A P_{t-1}}{E x p_{t-1}}\right) \frac{E x p_{t}}{A s s_{t-1}} \\
& +\alpha_{3}\left(\frac{D e p_{t-1}}{G F A_{t-1}}\right)\left(\frac{G F A_{t}}{A s s_{t-1}}\right)+\varepsilon_{t}
\end{aligned}
$$

Where in addition to the variables that were considered for Eq. 3, these authors included the effect of inventories (Inv), expenses paid in advance $(E P A)$, accounts payable $(A P)$, total expenses without the effect of depreciation and amortization $(E x p)$, depreciation and amortization (Dep) and gross fixed assets $(G F A)$.

The results of the regression analysis using the aforementioned models can be seen in Appendix C. In the case of the United Kingdom, the results validated in the previous section are maintained. In this way, it is possible to observe that, in general, according to different measures of opacity (calculated according to different estimates of DAs), there is no relationship between the opacity of the financial information and the idiosyncratic risk of the shares of companies traded on the stock market in the United Kingdom. Similarly, once we proceed to apply the analysis proposed by Hutton et al. (2009), taking into account the effect of company size, the regression results indicate that for large companies in the United Kingdom, the relationship between opacity and idiosyncratic risk is negative before the adoption of the IFRS, and once these financial reporting standards were adopted, this association tended to diminish.

Thus the marginal effect of opacity on idiosyncratic risk once the IFRS were implemented is 0.357 , 0.639 and 0.552 for the specifications that use the models by Jones (1991), Kothari et al. (2005) and 
Kang and Sivaramakrishnan (1995). In this same vein, the marginal effect prior to the adoption of the IFRS for large companies is $-2.294,-2.653$ and -1.275 . In this sense, only the model by Teoh et al. (1998) shows a coefficient for the interaction between the opacity variable and the IFRS variable that is positive, but not significant. In addition, the coefficients of determination for the specifications proposed for small companies in the United Kingdom are very low, which is in agreement with the findings in the previous section.

In the case of France, the results of the specifications enable us to establish that while in the previous section, it was possible to conclude that once the IFRS are adopted, the negative relationship shown between opacity and idiosyncratic risk becomes more important for all firms; this does not occur for any of the established models. Furthermore, and this time in agreement with the results revealed in panel B of Table 1, there is no statistically significant relationship between opacity and the idiosyncratic risk of the larger firms; at the same time, the fit of the specifications proposed for the smaller companies traded in France is very low. Once again, these results must therefore be interpreted with caution. At this point, the specifications related to smaller companies could indicate that there is apparently a negative relationship between opacity and the idiosyncratic risk for this group prior to the adoption of IFRS in 2005.

Finally, it is important to note that the dependent variable in our analyses is directly associated with the coefficient of determination of a regression on stock returns. Different authors have found a generalized reduction of these r-squares (R2) in the USA over time (Morck, Yeung \& Yu, 2000; Campbell, Lettau, Malkiel \& Xu, 2001; Jin \& Myers, 2006). Consequently, the idiosyncratic risk, according to the interpretation in this work, has increased and it could be considered that a less negative association of opacity with this risk, coinciding with the adoption of IFRS, could be falsely attributed as a positive effect of its entry into force.

Appendix D shows the evolution of R2 for the samples considered in the regressions for this study. The trend for R2 for both samples barely increases and appears to be cyclical; this minimizes any urge to attribute an effect to the adoption of IFRS, which simply reflects a generalized decrease in R2. 


\section{Discussion of the results}

In essence, the results indicate that at first glance, prior to the implementation of the IFRS, there is no relationship between the quality of financial information and the idiosyncratic risk of the stock in companies in the United Kingdom. This finding partially contradicts the first hypothesis proposed in this study, in that while there is no association between opacity and idiosyncratic risk before the implementation of IFRS, it is possible to note that this relationship remains after 2005; this could be interpreted as a compensation of the conditions that strengthen and restrict EM, which are involved in the adoption of these standards.

In spite of this, when we consider that the relationship between the quality of the financial information and the idiosyncratic risk, and the effect of the IFRS on said relationship, may be affected by the size of the companies that are being studied (as proposed in Hypothesis 3), the conclusions change. Accordingly, in the United Kingdom it is possible to confirm that the correlation among the analyzed variables is not the same for large companies as compared to smaller ones. Larger companies show a negative relationship between the opacity of their financial information and the idiosyncratic risk of their stock returns before 2005, but this relationship tends to disappear following the implementation of the IFRS. This fact evidences that the arguments in favor of the positive impact of IFRS on the quality of financial information prevail over those that indicate that these standards promote EM; it also reveals an argument in favor of the objectives stipulated by the IAS Regulation with regard to improving the quality of the financial reports. Accordingly, following the implementation of IFRS, we can argue that in the United Kingdom, the information provided by the financial statements helps provide investors with more criteria, as well as information provided by the financial sector or market to which a large company belongs (systematic risk) when assessing its capacity to generate future cash flows, which is reflected in the stock price and thus in its stock returns.

At this point, readers may note that the research concludes that it is possible to appreciate a positive effect of IFRS on the quality of financial information for large companies in the United Kingdom, since as was explained in sections 4 and 5, of the different models used in the literature to calculate the DAs, most demonstrate this relationship; in particular, mention should be made of those by Dechow et al. (1995), Kothari et al. (2005) and Kang and Sivaramakrishnan (1995).

That said, in the case of France, it is possible to observe that the results of sections 4 and 5 for companies in general are in agreement with what is proposed in Hypothesis 1. Prior to the implementation of IFRS, there was a negative relationship between the opacity of financial reports and 
the idiosyncratic risk of the stock returns of companies in general, but once these standards were implemented, it is not possible to observe that they have had any influence on the relationship between the quality of financial information and the idiosyncratic risk of a company's stock returns.

At this point, the results were considered from the section 5 in which the other approaches to EM measured as the estimated DA revealed that there is no impact on the marginal effect of opacity on the idiosyncratic risk once the IFRS were adopted. Likewise, readers must consider that this effect is weak in specification 2 of panel $B$, as very low significance is reached ( $p$-value $<0.10$ ).

In light of this, it could be argued that factors such as professional judgment, valuation criteria (such as fair value), among other aspects that support EM, are compensated by the improvement in the quality of accounting standards. This being the case, with regard to company size, contrary to what was expected by Hypothesis 3, the effect of IFRS on the relationship between the quality of financial information and idiosyncratic risk does not change when company size is taken into account.

From these findings, it is possible to establish that the effect of the IFRS on the relationship between the quality of financial information and the idiosyncratic risk of the companies' stock returns is different in the countries analyzed. As evidenced by the results, larger companies in the United Kingdom experience a benefit from the implementation of IFRS that their peers in France do not after adopting these standards. This coincides with what was expected by Hypothesis 2 and with various studies that make note of the advantages when implementing IFRS in countries such as the United Kingdom, with a Common Law system and strict rigor in the application of accounting standards; just the opposite occurs in countries like France, which have a Civil Code system and less rigor in the application of accounting norms (Daske et al., 2008; Doukakis, 2014; Jeanjean \& Stolowy, 2008; Liao et al., 2012; Soderstrom \& Sun, 2007; Van Tendeloo \& Vanstraelen, 2005; Von Koch et al., 2014).

On the other hand, in terms of the analysis of the smallest companies in both countries, while the models used show a poor fit and thus the results are not conclusive, they do indicate an aspect that could be addressed in future studies. In the case of France, it would seem that the smallest companies are the ones that show a negative association between the quality of financial information and the idiosyncratic risk, which could indicate that the results presented for the companies in general may be influenced to a large extent by the behavior of the smallest companies. This position, however, requires a more exhaustive analysis, due to the low coefficient of determination of the specifications related to this group of companies (this can be verified to a large extent from specifications 3 and 4 of Table 1 and the robustness tests). 
In the same vein, this work also considers that the significance and sign of the dichotomous variable IFRS in the panels of Table 1 (as for most of the specifications of the robustness tests) for all companies and the largest ones in the United Kingdom and France may be a finding to consider in future research. This can be seen through the change in the intercept of the regressions presented and would indicate that while the IFRS have a positive impact on the quality of information by diminishing the EM, thus improving the quality of financial information and its impact on the idiosyncratic risk, as explained earlier, the adoption in 2005 of these standards in the United Kingdom and France would be associated with a clear reduction in the idiosyncratic risk of the stock returns for companies in these countries.

\section{Conclusions}

Following Hutton et al. (2009), we studied the effect of the IFRS mandatory implementation in the United Kingdom and France on the quality of financial information and stock returns of companies, analyzing the relationship between opacity, a proxy for the quality of the information presented in the financial reports, and the idiosyncratic risk of the firms' stock returns in these two countries. The results of the regressions analysis indicate that for the United Kingdom this relationship is not observable a priori regardless of the adoption of the IFRS, unless the companies' size is factored into the regressions. This country, which has a Common Law legal system and demands rigorous compliance with accounting standards, shows an increase in the quality of financial reports (from companies traded on the stock market) in association with the mandatory implementation of the IFRS (after 2005) for companies with higher market capitalization. This result extends the conclusions of studies such as those conducted by Barth et al. (2008), Jeanjean and Stolowy (2008) and Liao et al. (2012), who report improvements in the quality of financial information in the United Kingdom following the implementation of IFRS.

Furthermore, this work found evidence that suggests the existence of a negative effect of the implementation of IFRS on the idiosyncratic risk for both countries. We believe that this is worthy of more in-depth investigation in future studies. Finally, while this work uses a more robust methodology in order to overcome the design problems of previous research projects, at no point was it intended to reach a definitive conclusion with regard to the discussion of the effects that the mandatory adoption of IFRS have had on the quality of financial information in the EU. It simply seeks to contribute to 
this discussion, suggesting the use of a new approach that would permit the detailed analysis of the possible existence of these effects.

Panel A. United Kingdom

\begin{tabular}{|c|c|c|c|c|c|c|}
\hline Dependent variable & (1) & (2) & (3) & (4) & (5) & (6) \\
\hline Idiosyncratic risk & $\begin{array}{l}\text { All } \\
b / p\end{array}$ & $\begin{array}{l}\text { All } \\
b / p\end{array}$ & $\begin{array}{l}\text { Small } \\
\mathrm{b} / \mathrm{p}\end{array}$ & $\begin{array}{l}\text { Small } \\
\mathrm{b} / \mathrm{p}\end{array}$ & $\begin{array}{l}\text { Big } \\
\mathrm{b} / \mathrm{p}\end{array}$ & $\begin{array}{l}\text { Big } \\
b / p\end{array}$ \\
\hline Opacity & $\begin{array}{l}0.009 \\
{[0.661]}\end{array}$ & $\begin{array}{l}-0.122 \\
{[0.520]}\end{array}$ & $\begin{array}{l}0.022 \\
{[0.243]}\end{array}$ & $\begin{array}{l}0.860^{* *} \\
{[0.026]}\end{array}$ & $\begin{array}{l}-0.122 \\
{[0.752]}\end{array}$ & $\begin{array}{l}-2.096^{* *} \\
{[0.033]}\end{array}$ \\
\hline Sector Variation & $\begin{array}{l}1.983^{* *} \\
{[0.011]}\end{array}$ & $\begin{array}{l}2.520^{* * *} \\
{[0.001]}\end{array}$ & $\begin{array}{l}6.130^{* *} \\
{[0.027]}\end{array}$ & $\begin{array}{l}6.154^{* *} \\
{[0.026]} \\
\end{array}$ & $\begin{array}{l}29.706^{* * *} \\
{[0.000]}\end{array}$ & $\begin{array}{l}29.422^{* * *} \\
{[0.000]}\end{array}$ \\
\hline Size & $\begin{array}{l}-0.273^{* * *} \\
{[0.000]}\end{array}$ & $\begin{array}{l}-0.274 * * * \\
{[0.000]}\end{array}$ & & & & \\
\hline Market to book ratio & $\begin{array}{l}-0.001 \\
{[0.883]}\end{array}$ & $\begin{array}{l}0.002 \\
{[0.856]}\end{array}$ & $\begin{array}{l}-0.037 * * \\
{[0.034]}\end{array}$ & $\begin{array}{l}-0.041 * * \\
{[0.022]}\end{array}$ & $\begin{array}{l}-0.009 \\
{[0.647]}\end{array}$ & $\begin{array}{l}-0.008 \\
{[0.685]}\end{array}$ \\
\hline Indebtedness & $\begin{array}{l}-0.201 * * \\
{[0.013]}\end{array}$ & $\begin{array}{l}-0.268^{* * *} \\
{[0.001]}\end{array}$ & $\begin{array}{l}-0.004 \\
{[0.978]}\end{array}$ & $\begin{array}{l}-0.003 \\
{[0.981]}\end{array}$ & $\begin{array}{l}-0.150 \\
{[0.488]}\end{array}$ & $\begin{array}{l}-0.208 \\
{[0.325]}\end{array}$ \\
\hline ROE & $\begin{array}{l}0.131 * \\
{[0.095]}\end{array}$ & $\begin{array}{l}0.089 \\
{[0.250]}\end{array}$ & $\begin{array}{l}-0.048 \\
{[0.633]}\end{array}$ & $\begin{array}{l}-0.045 \\
{[0.658]}\end{array}$ & $\begin{array}{l}-0.693^{* * *} \\
{[0.009]}\end{array}$ & $\begin{array}{l}-0.585^{* *} \\
{[0.025]}\end{array}$ \\
\hline Asymmetry & $\begin{array}{l}0.047 * * * \\
{[0.001]}\end{array}$ & $\begin{array}{l}0.044 * * * \\
{[0.001]}\end{array}$ & $\begin{array}{l}0.062^{* * *} \\
{[0.001]}\end{array}$ & $\begin{array}{l}0.061 * * * \\
{[0.001]}\end{array}$ & $\begin{array}{l}0.063 \\
{[0.254]}\end{array}$ & $\begin{array}{l}0.017 \\
{[0.754]}\end{array}$ \\
\hline Kurtosis & $\begin{array}{l}0.023^{* * *} \\
{[0.000]}\end{array}$ & $\begin{array}{l}0.022^{* * *} \\
{[0.000]}\end{array}$ & $\begin{array}{l}0.015^{* * *} \\
{[0.005]}\end{array}$ & $\begin{array}{l}0.015^{* * *} \\
{[0.006]}\end{array}$ & $\begin{array}{l}0.085^{* * *} \\
{[0.000]}\end{array}$ & $\begin{array}{l}0.075^{* * *} \\
{[0.000]}\end{array}$ \\
\hline IFRS & & $\begin{array}{l}-0.292^{* * *} \\
{[0.000]}\end{array}$ & & $\begin{array}{l}0.086 \\
{[0.271]}\end{array}$ & & $\begin{array}{l}-0.608^{* * *} \\
{[0.000]}\end{array}$ \\
\hline Opacity \# IFRS & & $\begin{array}{l}0.139 \\
{[0.464]}\end{array}$ & & $\begin{array}{l}-0.839 * * \\
{[0.030]}\end{array}$ & & $\begin{array}{l}2.271 \text { ** } \\
{[0.031]}\end{array}$ \\
\hline Intercept & \begin{tabular}{|l}
$2.866^{* * *}$ \\
{$[0.000]$}
\end{tabular} & $\begin{array}{l}3.066^{* * *} \\
{[0.000]}\end{array}$ & $\begin{array}{l}2.001 * * * \\
{[0.000]}\end{array}$ & $\begin{array}{l}1.914 * * * \\
{[0.000]}\end{array}$ & $\begin{array}{l}0.319^{* *} \\
{[0.029]}\end{array}$ & $\begin{array}{l}0.759 * * * \\
{[0.000]}\end{array}$ \\
\hline Obs. & 3677 & 3677 & 800 & 800 & 993 & 993 \\
\hline R2 & 0.3495 & 0.3660 & 0.0368 & 0.0428 & 0.1015 & 0.1498 \\
\hline R2 adjusted & 0.3481 & 0.3642 & 0.0283 & 0.0319 & 0.0951 & 0.1420 \\
\hline
\end{tabular}


Panel B. France

\begin{tabular}{|c|c|c|c|c|c|c|}
\hline Dependent variable & (1) & (2) & (3) & (4) & (5) & (6) \\
\hline Idiosyncratic risk & $\begin{array}{l}\text { All } \\
b / p\end{array}$ & $\begin{array}{l}\text { All } \\
b / p\end{array}$ & $\begin{array}{l}\text { Small } \\
b / p\end{array}$ & $\begin{array}{l}\text { Small } \\
b / p\end{array}$ & $\begin{array}{l}\text { Big } \\
b / p\end{array}$ & $\begin{array}{l}\text { Big } \\
b / p\end{array}$ \\
\hline Opacity & $\begin{array}{l}-0.024 \\
{[0.141]}\end{array}$ & $\begin{array}{l}-0.021 \\
{[0.220]}\end{array}$ & $\begin{array}{l}-0.014 \\
{[0.368]}\end{array}$ & $\begin{array}{l}-0.014 \\
{[0.398]}\end{array}$ & $\begin{array}{l}-0.506 \\
{[0.537]}\end{array}$ & $\begin{array}{l}-0.503 \\
{[0.630]}\end{array}$ \\
\hline Sector Variation & $\begin{array}{l}58.556^{* * *} \\
{[0.000]}\end{array}$ & $\begin{array}{l}50.692^{* * *} \\
{[0.000]}\end{array}$ & $\begin{array}{l}27.003^{* * *} \\
{[0.000]}\end{array}$ & $\begin{array}{l}16.811^{* *} \\
{[0.017]}\end{array}$ & $\begin{array}{l}128.440^{* * *} \\
{[0.000]}\end{array}$ & $\begin{array}{l}120.032^{* * *} \\
{[0.000]}\end{array}$ \\
\hline Size & $\begin{array}{l}-0.229 * * * \\
{[0.000]}\end{array}$ & $\begin{array}{l}-0.226^{* * *} \\
{[0.000]}\end{array}$ & & & & \\
\hline Market to book ratio & $\begin{array}{l}-0.018 \\
{[0.106]}\end{array}$ & $\begin{array}{l}-0.026^{* *} \\
{[0.018]}\end{array}$ & $\begin{array}{l}0.004 \\
{[0.833]}\end{array}$ & $\begin{array}{l}-0.003 \\
{[0.866]}\end{array}$ & $\begin{array}{l}-0.064 * * \\
{[0.033]}\end{array}$ & $\begin{array}{l}-0.081 * * * \\
{[0.007]}\end{array}$ \\
\hline Indebtedness & $\begin{array}{l}-0.100 \\
{[0.296]}\end{array}$ & $\begin{array}{l}-0.253^{* * *} \\
{[0.009]}\end{array}$ & $\begin{array}{l}0.033 \\
{[0.858]}\end{array}$ & $\begin{array}{l}-0.055 \\
{[0.766]}\end{array}$ & $\begin{array}{l}0.330 \\
{[0.251]}\end{array}$ & $\begin{array}{l}0.155 \\
{[0.589]}\end{array}$ \\
\hline ROE & $\begin{array}{l}0.336^{* * *} \\
{[0.001]}\end{array}$ & $\begin{array}{l}0.288^{* * *} \\
{[0.003]}\end{array}$ & $\begin{array}{l}-0.098 \\
{[0.466]}\end{array}$ & $\begin{array}{l}-0.153 \\
{[0.256]}\end{array}$ & $\begin{array}{l}1.593^{* * *} \\
{[0.002]}\end{array}$ & $\begin{array}{l}1.775^{* * *} \\
{[0.000]}\end{array}$ \\
\hline Assymetry & $\begin{array}{l}0.088^{* * *} \\
{[0.000]}\end{array}$ & $\begin{array}{l}0.084^{* * *} \\
{[0.000]}\end{array}$ & $\begin{array}{l}0.042 \\
{[0.232]}\end{array}$ & $\begin{array}{l}0.042 \\
{[0.239]}\end{array}$ & $\begin{array}{l}0.145^{*} \\
{[0.059]}\end{array}$ & $\begin{array}{l}0.126^{*} \\
{[0.098]}\end{array}$ \\
\hline Kurtosis & $\begin{array}{l}0.019 * * * \\
{[0.002]}\end{array}$ & $\begin{array}{l}0.019 * * * \\
{[0.002]}\end{array}$ & $\begin{array}{l}0.012 \\
{[0.224]}\end{array}$ & $\begin{array}{l}0.013 \\
{[0.210]} \\
\end{array}$ & $\begin{array}{l}0.029 \\
{[0.166]}\end{array}$ & $\begin{array}{l}0.023 \\
{[0.270]}\end{array}$ \\
\hline Dependent variable & (1) & $(2)$ & (3) & (4) & (5) & $(6)$ \\
\hline IFRS & & $\begin{array}{l}-0.278^{* * *} \\
{[0.000]}\end{array}$ & & $\begin{array}{l}-0.240^{* * *} \\
{[0.001]}\end{array}$ & & $\begin{array}{l}-0.291 * * \\
{[0.011]}\end{array}$ \\
\hline Opacity \# IFRS & & $\begin{array}{l}-0.072 \\
{[0.228]}\end{array}$ & & $\begin{array}{l}-0.041 \\
{[0.551]}\end{array}$ & & $\begin{array}{l}-1.792 \\
{[0.294]}\end{array}$ \\
\hline Intercept & $\begin{array}{l}2.136^{* * *} \\
{[0.000]}\end{array}$ & $\begin{array}{l}2.386^{* * *} \\
{[0.000]}\end{array}$ & \begin{tabular}{|l}
$1.476^{* * *}$ \\
{$[0.000]$}
\end{tabular} & $\begin{array}{l}1.692^{* * *} \\
{[0.000]}\end{array}$ & $\begin{array}{l}-0.608^{* * *} \\
{[0.007]}\end{array}$ & $\begin{array}{l}-0.266 \\
{[0.272]}\end{array}$ \\
\hline Obs. & 2941 & 2941 & 739 & 739 & 588 & 588 \\
\hline $\mathbf{R} 2$ & 0.3147 & 0.3293 & 0.0332 & 0.0505 & 0.2582 & 0.2786 \\
\hline R2_adjusted & 0.3128 & 0.3270 & 0.0239 & 0.0388 & 0.2492 & 0.2674 \\
\hline
\end{tabular}

Panels A and B report the results for the regressions of the idiosyncratic risk of the stock returns according to the opacity of the financial statements and a series of control variables for companies traded on the stock exchanges in the United Kingdom and France. The control variables include the variation of the returns in the sector to which the company belongs, the size of the company (measured as the logarithm of its market capitalization), the coefficient between its market capitalization and its book value, its level of indebtedness, its return on equity (ROE), asymmetry coefficient and the kurtosis of its stock return. The size, the coefficient of the market book value and the indebtedness lag one tax period behind. The standard errors of the regressions were estimated in a robust manner. The $\mathrm{p}$-values are shown in brackets.***, **, * indicate significance at $0.01,0.5$ and 0.10 .

Table 1. Relationship between idiosyncratic risk and opacity

\section{References}

Aisbitt, S. (2006). Assessing the Effect of the Transition to IFRS on Equity: The Case of the FTSE 100. Accounting in Europe, 3(1), 117-133. https://doi.org/10.1080/09638180600920293

Baber, W.R., Chen, S., \& Kang, S.H. (2006). Stock price reaction to evidence of earnings management: Implications for supplementary financial disclosure. Review of Accounting Studies, 11(1), 5-19. https://doi.org/10.1007/s11142-006-6393-0 
Barth, M.E., Landsman, W.R., \& Lang, M.H. (2008). International Accounting Standards and Accounting Quality. Journal of Accounting Research, 46(3), 467-498. https://doi.org/10.1111/j.1475679X.2008.00287.x

Beekes, W., Pope, P., \& Young, S. (2004). The link between earnings timeliness, earnings conservatism and board composition: Evidence from the UK. Corporate Governance: An International Review, 12(1), 47-59. https://doi.org/10.1111/j.1467-8683.2004.00342.x

Bergstresser, D., \& Philippon, T. (2006). CEO incentives and earnings management. Journal of Financial Economics, 80, 511-529. https://doi.org/10.1016/j.jineco.2004.10.011

Beyer, A. (2009). Capital market prices, management forecasts, and earnings management. Accounting Review, 84, 1713-1747. https://doi.org/10.2308/accr.2009.84.6.1713

Brüggemann, U., Hitz, J.-M., \& Sellhorn, T. (2013). Intended and Unintended Consequences of Mandatory IFRS Adoption: A Review of Extant Evidence and Suggestions for Future Research. European Accounting Review, 22(1), 1-37. https://doi.org/10.1080/09638180.2012.718487

Callao, S., \& Jarne, J.I. (2010). Have IFRS Affected Earnings Management in the European Union?. Accounting in Europe, 72(2), 159-189. https://doi.org/10.1080/17449480.2010.511896

Campbell, J.Y., Lettau, M., Malkiel, B.G., \& Xu, Y. (2001). Have individual stocks become more volatile? An empirical exploration of idiosyncratic risk. The Journal of Finance, 56(1), 1-43. https://doi.org/10.1111/0022-1082.00318

Cang, Y., Chu, Y., \& Lin, T.W. (2014). An exploratory study of earnings management detectability, analyst coverage and the impact of IFRS adoption: Evidence from China. Journal of Accounting and Public Policy, 33(4), 356-371. https://doi.org/10.1016/j.jaccpubpol.2014.04.003

Capkun, V., \& Cazavan-Jeny, A. (2008). Earnings management and value relevance during the mandatory transition from local GAAPs to IFRS in Europe. Available at SSRN 1125716. Retrieved from: http://papers.ssrn.com/sol3/papers.cfm?abstract id=1125716 https://doi.org/10.2139/ssrn.1125716

Clarkson, P., Hanna, J.D., Richardson, G.D., \& Thompson, R. (2011). The impact of IFRS adoption on the value relevance of book value and earnings. Journal of Contemporary Accounting \& Economics, 7(1), 1-17. https://doi.org/10.1016/j.jcae.2011.03.001

Cormier, D., Demaria, S., Lapointe-Antunes, P., \& Teller, R. (2009). First-Time Adoption of IFRS, Managerial Incentives, and Value-Relevance: Some French Evidence. Journal of International Accounting Research, 8(2), 1-22. https://doi.org/10.2308/jiar.2009.8.2.1 
Cornett, M.M., Marcus, A.J., \& Tehranian, H. (2008). Corporate governance and pay-for-performance: The impact of earnings management. Journal of Financial Economics, 87(2), 357-373. https://doi.org/10.1016/j.jfineco.2007.03.003

Das, S., Kim, K., \& Patro, S. (2011). An analysis of managerial use and market consequences of earnings management and expectation management. Accounting Review, 86(6), 1935-1967.

Daske, H., Hail, L., Leuz, C., \& Verdi, R. (2008). Mandatory IFRS Reporting around the World: Early Evidence on the Economic Consequences. Journal of Accounting Research, 46(5), 1085-1142. https://doi.org/10.1111/j.1475-679X.2008.00306.x

Dechow, P.M., Hutton, A.P., Kim, J.H., \& Sloan, R.G. (2012). Detecting earnings management: A new approach. Journal of Accounting Research, 50(April 2011), 275-334. Retrieved from: http://onlinelibrary.wiley.com/doi/10.1111/j.1475-679X.2012.00449.x/full $\quad$ https://doi.org/10.1111/j.1475679X.2012.00449.x

Dechow, P.M., Sloan, R.G., \& Sweeney, A.P. (1995). Detecting Earnings Management. The Accounting Review, 70(2), 193-225.

Doukakis, L.C. (2014). The effect of mandatory IFRS adoption on real and accrual-based earnings management activities. Journal of Accounting and Public Policy, 33(6), 551-572. https://doi.org/10.1016/j.jaccpubpol.2014.08.006

Eierle, B., \& Haller, A. (2009). Does Size Influence the Suitability of the IFRS for Small and MediumSized Entities? - Empirical Evidence from Germany. Accounting in Europe, 6(2), 195-230. https://doi.org/10.1080/17449480903115779

Goodwin, J., \& Ahmed, K. (2006). The impact of international financial reporting standards: Does size matter?. Managerial Auditing Journal, 21(5), 460-475. https://doi.org/10.1108/02686900610667247

Haller, A., Ernstberger, J., \& Froschhammer, M. (2009). Implications of the mandatory transition from national GAAP to IFRS - Empirical evidence from Germany. Advances in Accounting, 25(2), 226-236. https://doi.org/10.1016/j.adiac.2009.08.007

Healy, P., \& Wahlen, J. (1999). A Review of the Earnings Management Literature and Its Implications for Standard Setting. Accounting Horizons, 13(4), 365-383. https://doi.org/10.2308/acch.1999.13.4.365

Hutton, A.P., Marcus, A.J., \& Tehranian, H. (2009). Opaque financial reports, R2, and crash risk. Journal of Financial Economics, 94(1), 67-86. https://doi.org/10.1016/j.jfineco.2008.10.003 
Jeanjean, T., \& Stolowy, H. (2008). Do accounting standards matter? An exploratory analysis of earnings management before and after IFRS adoption. Journal of Accounting and Public Policy, 27(6), 480-494. https://doi.org/10.1016/j.jaccpubpol.2008.09.008

Jones, J.J. (1991). Earnings Management During Import Relief Investigations. Journal of Accounting Research, 29(2), 193-228. https://doi.org/10.2307/2491047

Jin, L., \& Myers, S.C. (2006). R2 around the world: New theory and new tests. Journal of financial Economics, 79(2), 257-292. https://doi.org/10.1016/j.jfineco.2004.11.003

Kang, Q., Liu, Q., \& Qi, R. (2010). Predicting Stock Market Returns with Aggregate Discretionary Accruals. Journal of Accounting Research, 48(4), 815-858. https://doi.org/10.1111/j.1475-679X.2010.00379.x

Kang, S.H., \& Sivaramakrishnan, K. (1995). Issues in Testing Earnings Management and an Instrumental Variable Approach. Journal of Accounting Research, 33(2), 353-367. https://doi.org/10.2307/2491492

Konan, C., Chan, L.K C., Jegadeesh, N., \& Lakonishok, J. (2006). Earnings Quality and Stock Returns. Journal of Business, 79(3), 1041-1082. https://doi.org/10.1086/500669

Kothari, S.P., Leone, A.J., \& Wasley, C.E. (2005). Performance matched discretionary accrual measures. Journal of Accounting and Economics, 39(1), 163-197. https://doi.org/10.1016/j.jacceco.2004.11.002

La Porta, R., Lopez-de-Silanes, F., Shleifer, A., \& Vishny, R.W. (1998). Law and Finance. Journal of Political Economy, 106(6), 1113-1155. https://doi.org/10.1086/250042

Li, L., Francis, B.B., \& Hasan, I. (2011). Firms’ Real Earnings Management and Subsequent Stock Price Crash Risk. SSRN Electronic Journal. https://doi.org/10.2139/ssrn.1740044

Liao, Q., Sellhorn, T., \& Skaife, H.A. (2012). The Cross-Country Comparability of IFRS Earnings and Book Values: Evidence from France and Germany. Journal of International Accounting Research, 11(1), 155-184. https://doi.org/10.2308/jiar-10225

Louis, H. (2004). Earnings management and the market performance of acquiring firms. Journal of Financial Economics, 74(1), 121-148. https://doi.org/10.1016/j.jfineco.2003.08.004

Morck, R., Yeung, B., \& Yu, W. (2000). The information content of stock markets: why do emerging markets have synchronous stock price movements?. Journal of financial economics, 58(1), 215-260. https://doi.org/10.1016/S0304-405X(00)00071-4

Nobes, C., \& Perramon, J. (2013). Firm size and national profiles of IFRS policy choice. Australian Accounting Review, 23(3), 208-215. https://doi.org/10.1111/j.1835-2561.2012.00203.x 
Pelucio-Grecco, M.C., Geron, C.M.S., Grecco, G.B., \& Lima, J.P.C. (2014). The effect of IFRS on earnings management in Brazilian non-financial public companies. Emerging Markets Review, 21, 42-66. https://doi.org/10.1016/j.ememar.2014.07.001

Soderstrom, N.S., \& Sun, K.J. (2007). IFRS Adoption and Accounting Quality: A Review. European Accounting Review, 16(4), 675-702. https://doi.org/10.1080/09638180701706732

Teoh, S.H., Welch, I., \& Wong, T.J. (1998). Earnings management and the underperformance of seasoned equity offerings. Journal of Financial Economics, 50(1), 63-99. https://doi.org/10.1016/S0304405X(98)00032-4

Van Tendeloo, B., \& Vanstraelen, A. (2005). Earnings management under German GAAP versus IFRS. European Accounting Review, 14(1), 155-180. https://doi.org/10.1080/0963818042000338988

Von Koch, C., Nilsson, O., Jonsson, M., \& Jansson, A. (2014). An Empirical Study of the Method Effect in Analysing the Adoption of IFRS. Accounting and Finance Research, 3(2), 153-169. https://doi.org/10.5430/afr.v3n2p153

Watts, R.L., \& Zimmerman, J.L. (1990). Positive Accounting Theory: A Ten Year Perspective. The Accounting Review, 65(1), 131-156.

Zéghal, D., Chtourou, S., \& Sellami, Y.M. (2011). An analysis of the effect of mandatory adoption of IAS/IFRS on earnings management. Journal of International Accounting, Auditing and Taxation, 20(2), 61-72. https://doi.org/10.1016/j.intaccaudtax.2011.06.001

Zhang, Y., Uchida, K., \& Bu, H. (2013). How do accounting standards and insiders' incentives affect earnings management? Evidence from China. Emerging Markets Review, 16(23330107), 78-99. https://doi.org/10.1016/j.ememar.2013.04.002 


\section{Appendices}

\section{Appendix A. Definitions of variables}

\begin{tabular}{|c|c|}
\hline Variable & Definition \\
\hline$T A_{t}$ & $\begin{array}{l}\text { Total Accruals of a company. Correspond to the difference between net profits (excluding the effects of } \\
\text { the discontinuity of operations, changes in accounting practices, natural disasters and minority interests) } \\
\text { and the cash generated by operating activities (Hutton, Marcus \& Tehranian, 2009). }\end{array}$ \\
\hline$\Delta$ Sales $_{t}$ & Year-on-year change in net sales revenue. \\
\hline$\Delta A R_{t}$ & Year-on-year change in accounts receivable. \\
\hline$\triangle P P E_{t}$ & Year-on-year change in property, plant and equipment (net). \\
\hline$A s s_{t-1}$ & First lag of Total Assets. \\
\hline $\mathrm{RO} A_{t}$ & Return over Assets. \\
\hline$D A_{t}$ & $\begin{array}{l}\text { Discretionary accruals of a firm. They are estimated from the EM model. In the results section they are } \\
\text { estimated based on the Modified Jones Model, Eq. 3, but this specification changes for the results of } \\
\text { robustness tests, where other EM models are incorporated. }\end{array}$ \\
\hline Opacity & $\begin{array}{l}\text { As the quality of financial information that is estimated from the sum of the absolute values of each of } \\
\text { the three lags of discretionary accruals of a firm. See Ec. } 4 \text { section in Methodology for more details. }\end{array}$ \\
\hline $\begin{array}{l}\text { Sector } \\
\text { Variation }\end{array}$ & Variance of the annual returns of the industry to which it belongs to a firm. \\
\hline Size & $\begin{array}{l}\text { Natural logarithm of the stock market capitalization of a company. Market capitalization is measured at } \\
\text { the beginning of the fiscal period and is computed as the product between the price and the number of } \\
\text { shares outstanding for a firm, adjusting for the effect of splits and share rights. }\end{array}$ \\
\hline $\begin{array}{l}\text { Market to book } \\
\text { ratio }\end{array}$ & Ratio of market capitalization to book value at the beginning of a firm's fiscal period. \\
\hline Indebtednes & Ratio of total liabilities and assets at the beginning of a company's fiscal period. \\
\hline $\mathrm{ROE}$ & Return over Equity. \\
\hline Asymmetry & Coefficient of asymmetry of the distribution of returns of a firm for a given fiscal period. \\
\hline Kurtosis & Curtosis of the distribution of a firm's returns for a given fiscal period. \\
\hline IFRS & $\begin{array}{l}\text { Dichotomous variable that takes the value of } 1 \text { for periods after } 2005 \text { (mandatory adoption of IFRS in } \\
\text { the EU) and } 0 \text { otherwise. }\end{array}$ \\
\hline
\end{tabular}

\section{Appendix B. Descriptive statistics}

Panel A. United Kingdom

Period (1995-2005; 2007-2014)

Figures in millions of GBP

\begin{tabular}{|l|r|r|r|r|r|}
\hline Variable & \multicolumn{1}{|c|}{ Obs } & \multicolumn{1}{c|}{ Mean } & \multicolumn{1}{c|}{ St. Dev. } & \multicolumn{1}{c|}{ Min } & \multicolumn{1}{c|}{ Max } \\
\hline Market Cap. & 3,677 & $2,094.24$ & $8,324.92$ & 0.48 & $121,232.90$ \\
\hline Equity (Book value) & 3,677 & 920.42 & $4,188.25$ & $(95.34)$ & $78,719.67$ \\
\hline Liabilities (Total) & 3,677 & $1,346.45$ & $6,051.17$ & 0.02 & $116,439.50$ \\
\hline Assets (Total) & 3,677 & $2,266.95$ & $10,080.34$ & 0.28 & $188,966.40$ \\
\hline Net profit & 3,677 & 146.09 & 766.06 & $(2,152.49)$ & $16,277.20$ \\
\hline Cash from operating activities & 3,677 & 233.99 & $1,091.12$ & $(522.00)$ & $19,897.25$ \\
\hline Revenues & 3,677 & $2,165.30$ & $11,030.67$ & - & $242,476.20$ \\
\hline Property, plant and equipment (Net) & 3,677 & 820.20 & $4,662.95$ & - & $83,879.08$ \\
\hline Accounts receivable & 3,677 & 220.08 & 973.63 & - & $19,529.30$ \\
\hline ROA (\%) & 3,677 & 3.93 & 9.85 & $(96.77)$ & 67.54 \\
\hline
\end{tabular}


Panel B. France

Period (1992-2005; 2007-2014)

Figures in millions of EUR

\begin{tabular}{|l|r|r|r|r|r|}
\hline Variable & \multicolumn{1}{|c|}{ Obs } & \multicolumn{1}{c|}{ Mean } & \multicolumn{1}{c|}{ St. Dev. } & \multicolumn{1}{c|}{ Min } & Max \\
\hline Market Cap. & 2,941 & $1,828.65$ & $5,721.34$ & 0.33 & $84,984.93$ \\
\hline Equity (Book value) & 2,941 & 943.90 & $3,106.92$ & $(5.09)$ & $47,472.42$ \\
\hline Liabilities (Total) & 2,941 & $1,863.64$ & $5,615.96$ & 0.09 & $69,134.09$ \\
\hline Assets (Total) & 2,941 & $2,807.29$ & $8,163.20$ & 0.87 & $94,810.38$ \\
\hline Net profit & 2,941 & 100.87 & 393.49 & $(8,084.29)$ & $5,150.62$ \\
\hline Cash from operating activities & 2,889 & 193.20 & 567.26 & $(758.49)$ & $8,460.42$ \\
\hline Revenues & 2,941 & $2,152.02$ & $5,859.35$ & - & $68,425.67$ \\
\hline Property, plant and equipment (Net) & 2,941 & 528.88 & $1,580.52$ & - & $15,355.77$ \\
\hline Accounts receivable & 2,941 & 400.00 & $1,079.43$ & - & $14,560.58$ \\
\hline ROA (\%) & 2,941 & 3.76 & 7.95 & $(67.10)$ & 92.27 \\
\hline
\end{tabular}

Appendix C. Results of the robustness regressions

Panel A. United Kingdom

\begin{tabular}{|c|c|c|c|c|c|c|}
\hline Specification & (1) & (2) & (3) & (4) & (5) & (6) \\
\hline Companies & $\begin{array}{l}\text { All } \\
\mathrm{b} / \mathrm{p}\end{array}$ & $\begin{array}{l}\text { All } \\
b / p\end{array}$ & $\begin{array}{l}\text { Small } \\
b / p\end{array}$ & $\begin{array}{l}\text { Small } \\
b / p\end{array}$ & $\begin{array}{l}\text { Big } \\
\mathrm{b} / \mathrm{p}\end{array}$ & $\begin{array}{l}\text { Big } \\
\mathrm{b} / \mathrm{p}\end{array}$ \\
\hline \multicolumn{7}{|c|}{ Panel A: Jones (1991) } \\
\hline Opacity & \begin{tabular}{|l|}
0.006 \\
{$[0.567]$}
\end{tabular} & $\begin{array}{l}-0.117 \\
{[0.669]}\end{array}$ & $\begin{array}{l}0.020 * * * \\
{[0.000]}\end{array}$ & $\begin{array}{l}0.979 * \\
{[0.063]}\end{array}$ & $\begin{array}{l}-0.193 \\
{[0.625]}\end{array}$ & $\begin{array}{l}-2.294 * * \\
{[0.048]}\end{array}$ \\
\hline Opacity \# IFRS & & $\begin{array}{l}0.131 \\
{[0.632]}\end{array}$ & & $\begin{array}{l}-0.961^{*} \\
{[0.068]}\end{array}$ & & $\begin{array}{l}2.651 * * \\
{[0.030]}\end{array}$ \\
\hline Obs. & 3677 & 3677 & 800 & 800 & 993 & 993 \\
\hline $\mathbf{R} 2$ & 0.3495 & 0.3659 & 0.0365 & 0.0439 & 0.1015 & 0.1507 \\
\hline R2_adjusted & 0.3481 & 0.3642 & 0.0280 & 0.0330 & 0.0952 & 0.1430 \\
\hline \multicolumn{7}{|c|}{ Panel A: Teoh et al. (1998) } \\
\hline Opacity & \begin{tabular}{|l|}
0.008 \\
{$[0.472]$}
\end{tabular} & $\begin{array}{l}-0.189 \\
{[0.558]}\end{array}$ & $\begin{array}{l}0.024 * * * \\
{[0.001]}\end{array}$ & $\begin{array}{l}0.838 \\
{[0.124]}\end{array}$ & $\begin{array}{l}-1.535^{* *} \\
{[0.040]}\end{array}$ & $\begin{array}{l}-2.863^{* *} \\
{[0.037]}\end{array}$ \\
\hline Opacity \# IFRS & & $\begin{array}{l}0.205 \\
{[0.525]}\end{array}$ & & $\begin{array}{l}-0.816 \\
{[0.134]}\end{array}$ & & $\begin{array}{l}1.084 \\
{[0.509]}\end{array}$ \\
\hline Obs. & 3677 & 3677 & 800 & 800 & 993 & 993 \\
\hline $\mathbf{R} 2$ & 0.3495 & 0.3660 & 0.0368 & 0.0423 & 0.1048 & 0.1532 \\
\hline R2_adjusted & 0.3481 & 0.3643 & 0.0283 & 0.0314 & 0.0984 & 0.1454 \\
\hline \multicolumn{7}{|c|}{ Panel A: Kothari et al. (2005) } \\
\hline Opacity & \begin{tabular}{|l|}
0.010 \\
{$[0.221]$}
\end{tabular} & $\begin{array}{l}-0.279 \\
{[0.320]}\end{array}$ & $\begin{array}{l}0.019 * * * \\
{[0.000]}\end{array}$ & $\begin{array}{l}0.805^{*} \\
{[0.078]}\end{array}$ & $\begin{array}{l}-0.146 \\
{[0.633]}\end{array}$ & $\begin{array}{l}-2.653 * * \\
{[0.010]}\end{array}$ \\
\hline Opacity \# IFRS & & $\begin{array}{l}0.299 \\
{[0.285]}\end{array}$ & & $\begin{array}{l}-0.787^{*} \\
{[0.085]}\end{array}$ & & $\begin{array}{l}3.292^{* * *} \\
{[0.002]}\end{array}$ \\
\hline Obs. & 3677 & 3677 & 800 & 800 & 993 & 993 \\
\hline $\mathbf{R} 2$ & 0.3495 & 0.3664 & 0.0365 & 0.0425 & 0.1015 & 0.1557 \\
\hline $\mathbf{R} 2 \_$adjusted & 0.3481 & 0.3647 & 0.0279 & 0.0316 & 0.0951 & 0.1480 \\
\hline \multicolumn{7}{|c|}{ Panel A: KS Model } \\
\hline Opacity & \begin{tabular}{|l|}
0.010 \\
{$[0.194]$}
\end{tabular} & $\begin{array}{l}-0.216 \\
{[0.188]}\end{array}$ & $\begin{array}{l}0.014 * * * \\
{[0.000]}\end{array}$ & $\begin{array}{l}-0.091 \\
{[0.786]}\end{array}$ & $\begin{array}{l}-0.362 \\
{[0.232]}\end{array}$ & $\begin{array}{l}-1.275^{* *} \\
{[0.034]}\end{array}$ \\
\hline Opacity \# IFRS & & $\begin{array}{l}0.235 \\
{[0.152]}\end{array}$ & & $\begin{array}{l}0.106 \\
{[0.753]}\end{array}$ & & $\begin{array}{l}1.827 * * * \\
{[0.007]}\end{array}$ \\
\hline Obs. & 3677 & 3677 & 800 & 800 & 993 & 993 \\
\hline $\mathbf{R} 2$ & 0.3495 & 0.3663 & 0.0358 & 0.0362 & 0.1026 & 0.1521 \\
\hline R2_adjusted & 0.3481 & 0.3645 & 0.0273 & 0.0252 & 0.0962 & 0.1443 \\
\hline
\end{tabular}


Panel B. France

\begin{tabular}{|c|c|c|c|c|c|c|}
\hline Specification & (1) & (2) & (3) & (4) & (5) & (6) \\
\hline Companies & $\begin{array}{l}\text { All } \\
b / p\end{array}$ & $\begin{array}{l}\text { All } \\
b / p\end{array}$ & $\begin{array}{l}\text { Small } \\
b / p\end{array}$ & $\begin{array}{l}\text { Small } \\
b / p\end{array}$ & $\begin{array}{l}\text { Big } \\
b / p\end{array}$ & $\begin{array}{l}\text { Big } \\
\mathrm{b} / \mathrm{p}\end{array}$ \\
\hline \multicolumn{7}{|c|}{ Panel A: Jones (1991) } \\
\hline Opacity & \begin{tabular}{|l}
$-0.022 * *$ \\
{$[0.043]$}
\end{tabular} & $\begin{array}{l}-0.020 * * * \\
{[0.004]}\end{array}$ & \begin{tabular}{|l}
$-0.013 * *$ \\
{$[0.011]$}
\end{tabular} & \begin{tabular}{|l}
$-0.014 * * *$ \\
{$[0.000]$}
\end{tabular} & $\begin{array}{l}-0.447 \\
{[0.613]}\end{array}$ & $\begin{array}{l}-0.759 \\
{[0.573]}\end{array}$ \\
\hline Opacity \# IFRS & & $\begin{array}{l}-0.072 \\
{[0.141]}\end{array}$ & & $\begin{array}{l}-0.024 \\
{[0.725]}\end{array}$ & & $\begin{array}{l}-0.495 \\
{[0.768]}\end{array}$ \\
\hline Obs. & 2941 & 2941 & 739 & 739 & 588 & 588 \\
\hline $\mathbf{R} 2$ & 0.3146 & 0.3292 & 0.0330 & 0.0500 & 0.2580 & 0.2763 \\
\hline $\mathrm{R} 2$ adjusted & 0.3127 & 0.3269 & 0.0237 & 0.0383 & 0.2490 & 0.2650 \\
\hline \multicolumn{7}{|c|}{ Panel A: Teoh et al. (1998) } \\
\hline Opacity & \begin{tabular}{|l}
$-0.022^{* *}$ \\
{$[0.046]$}
\end{tabular} & $\begin{array}{l}-0.021 * * * \\
{[0.008]}\end{array}$ & \begin{tabular}{|l}
$-0.013 * * *$ \\
{$[0.005]$}
\end{tabular} & $\begin{array}{l}-0.013 * * * \\
{[0.000]}\end{array}$ & $\begin{array}{l}-0.834 \\
{[0.443]}\end{array}$ & $\begin{array}{l}-1.395 \\
{[0.238]}\end{array}$ \\
\hline Opacity \# IFRS & & $\begin{array}{l}-0.091 \\
{[0.176]}\end{array}$ & & $\begin{array}{l}-0.066 \\
{[0.392]}\end{array}$ & & $\begin{array}{l}-2.043 \\
{[0.503]}\end{array}$ \\
\hline Obs. & 2957 & 2957 & 739 & 739 & 589 & 589 \\
\hline $\mathbf{R} 2$ & 0.3154 & 0.3300 & 0.0330 & 0.0506 & 0.2595 & 0.2786 \\
\hline R2_adjusted & 0.3136 & 0.3277 & 0.0237 & 0.0389 & 0.2505 & 0.2674 \\
\hline \multicolumn{7}{|c|}{ Panel A: Kothari et al. (2005) } \\
\hline Opacity & \begin{tabular}{|l}
$-0.022^{* *}$ \\
{$[0.042]$}
\end{tabular} & $\begin{array}{l}-0.021 * * * \\
{[0.005]}\end{array}$ & \begin{tabular}{|l}
$-0.014^{* *}$ \\
{$[0.012]$}
\end{tabular} & \begin{tabular}{|l}
$-0.014 * * *$ \\
{$[0.000]$}
\end{tabular} & $\begin{array}{l}-0.352 \\
{[0.609]}\end{array}$ & $\begin{array}{l}-1.277 \\
{[0.324]}\end{array}$ \\
\hline Opacity \# IFRS & & $\begin{array}{l}-0.066 \\
{[0.168]}\end{array}$ & & $\begin{array}{l}-0.050 \\
{[0.429]}\end{array}$ & & $\begin{array}{l}0.740 \\
{[0.600]}\end{array}$ \\
\hline Obs. & 2941 & 2941 & 739 & 739 & 588 & 588 \\
\hline $\mathbf{R} 2$ & 0.3146 & 0.3292 & 0.0332 & 0.0507 & 0.2580 & 0.2767 \\
\hline R2_adjusted & 0.3127 & 0.3269 & 0.0239 & 0.0390 & 0.2490 & 0.2654 \\
\hline \multicolumn{7}{|c|}{ Panel A: KS Model } \\
\hline Opacity & \begin{tabular}{|l}
$-0.156^{* * *}$ \\
{$[0.001]$}
\end{tabular} & \begin{tabular}{|l}
$-0.110^{*}$ \\
{$[0.064]$}
\end{tabular} & $\begin{array}{l}-0.069 \\
{[0.273]}\end{array}$ & \begin{tabular}{|l|}
0.048 \\
{$[0.500]$}
\end{tabular} & $\begin{array}{l}-0.231 \\
{[0.148]}\end{array}$ & $\begin{array}{l}-0.260 \\
{[0.665]}\end{array}$ \\
\hline Opacity \# IFRS & & $\begin{array}{l}-0.106 \\
{[0.174]}\end{array}$ & & $\begin{array}{l}-0.261^{* *} \\
{[0.012]}\end{array}$ & & $\begin{array}{l}0.037 \\
{[0.952]}\end{array}$ \\
\hline Obs. & 2660 & 2660 & 604 & 604 & 586 & 586 \\
\hline $\mathbf{R} 2$ & 0.3381 & 0.3527 & 0.0395 & 0.0679 & 0.2904 & 0.3061 \\
\hline R2_adjusted & 0.3361 & 0.3503 & 0.0282 & 0.0538 & 0.2818 & 0.2953 \\
\hline
\end{tabular}

The standard errors of the regressions were estimated in a robust manner. The p-values are shown in brackets.***, $* *, *$ indicate significance at $0.01,0.5$ and 0.10 .The betas and significance values of the control variables are omitted due to space restrictions; they are available upon request for interested readers. 


\section{Appendix D. Evolution of R2}
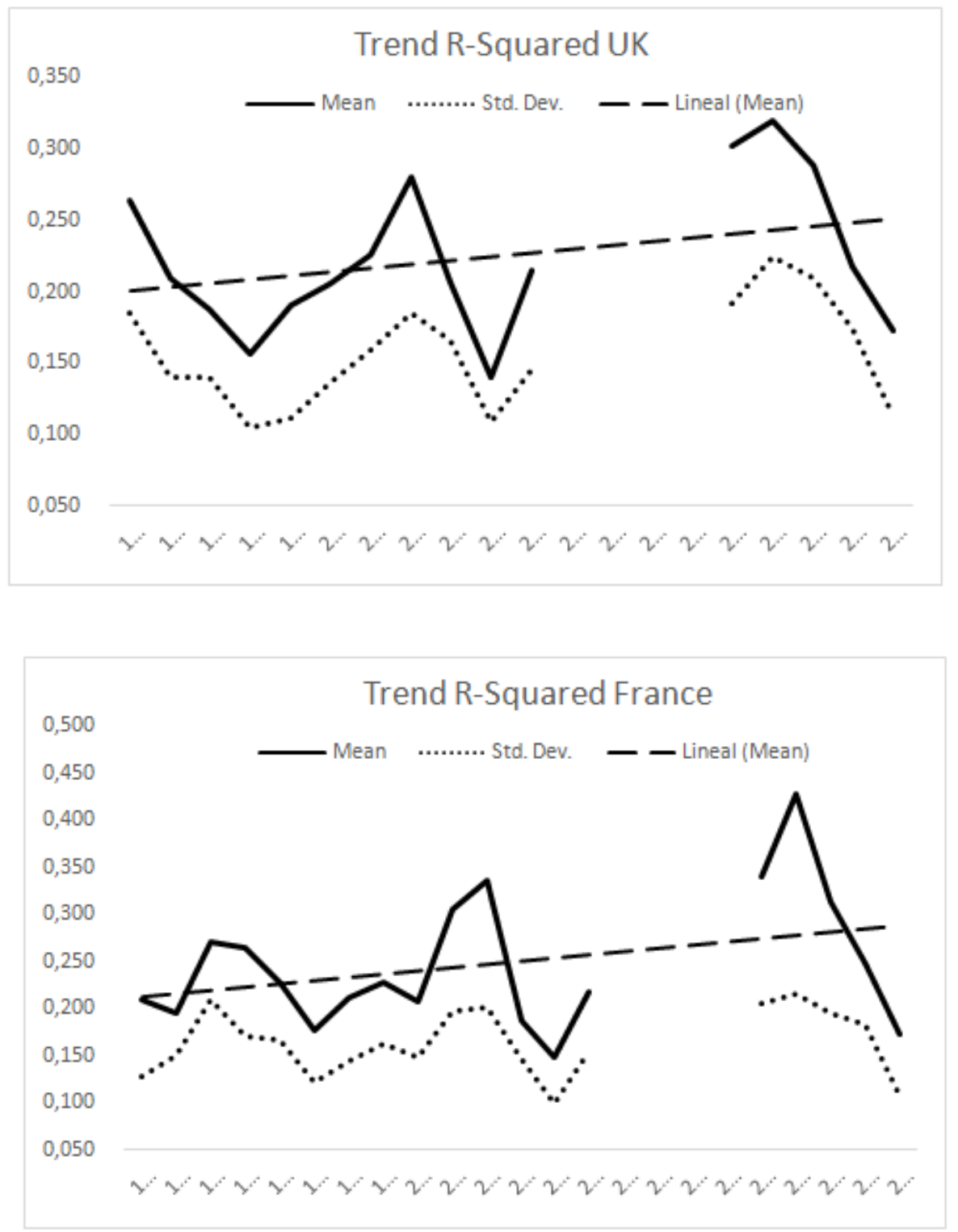

The graphs show the evolution of the R2 of the regression for the stock returns during the years studied. The solid line is the mean of the R2, while the dotted line is the standard deviation. The dashed line is a linear estimate of the trend of the mean.

Intangible Capital, 2017 (www.intangiblecapital.org)

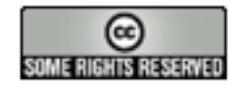

Article's contents are provided on an Attribution-Non Commercial 3.0 Creative commons license. Readers are allowed to copy, distribute and communicate article's contents, provided the author's and Intangible Capital's names are included. It must not be used for commercial purposes. To see the complete license contents, please visit http://creativecommons.org/licenses/by-nc/3.0/. 